https://doi.org/10.19195/0080-3626.63.5

PATRYK KOBLISCHKE

\title{
FAKSYMILIA JAKO TYP PUBLIKACJI KSIĄŻKOWEJ - DEFINICJA, TYPOLOGIA, EDYTORSTWO I FUNKCJE
}

Historia faksymiliów i stan badań. Pojęcie „faksymile” w opracowaniach zagranicznych. Faksymile a reprint. Typologia. Funkcjonalna koncepcja faksymile. Funkcje i cechy faksymile.

SŁOWA KLUCZOWE: faksymile, reprodukcja książki, edytorstwo naukowe

\section{WSTĘP}

Wezwaniu fac simile — „czyń podobne” — próbowali sprostać rzemieślnicy i artyści książki na przestrzeni dziejów. Wierne kopie dokumentów pełniły różne funkcje do momentu, aż utrwaliła się ostateczna forma reprodukcji — faksymile. Niestety w polskiej bibliologii istota i funkcja faksymiliów, zwłaszcza w kontekście międzynarodowej produkcji, była tematem podejmowanym bardzo rzadko. Brakuje przede wszystkim kompletnej pracy omawiającej faksymilia w wielu aspektach — definicyjnym, funkcjonalnym, materialnym.

Niniejszy tekst jest zatem próbą syntezy wiadomości o faksymiliach dostępnych w Internecie, literaturze naukowej i serwisach branżowych, a także prezentacją zjawiska, jakim są faksymilia współczesne. Mowa tu o obiektach wydanych po II połowie XX wieku do czasów obecnych, jednak z nastawieniem na wydania najnowsze - opublikowane po roku 2000 . W pracy podjęto również próbę zaprezentowania najważniejszych definicji, ujęć i typologii faksymiliów, opierając się na piśmiennictwie zarówno polskim, jak i zagranicznym. Zasadniczym celem było określenie współczesnych tendencji w zakresie tworzenia faksymiliów, a także wpływu przemian technologicznych na ich produkcję i recepcję. 


\section{HISTORIA FAKSYMILIÓW I STAN BADAŃ}

Faksymile, z łaciny fac simile, oznaczające dosłownie wezwanie „,zyń podobnie", ma, jak wskazuje Franz Unterkircher, analogiczną budowę wyrazu co faktotum ${ }^{1}$ — „rób wszystko”. Thomas Hilka podaje, że w języku angielskim termin ten był wykorzystywany już w XVII wieku ${ }^{2}$, w języku niemieckim przyjmuje się datę późniejszą. Ów termin wymienia jednak Joachim Heinrich Campe w słowniku ${ }^{3}$ wydanym w 1813 roku.

Trudno również stwierdzić, kiedy pojawiły się pierwsze faksymilia. Wynika to nie tylko z ogólnej tendencji do tworzenia kopii (albowiem jak pisze Walter Benjamin: „In principle a work of art has always been reproducible. Man-made artifacts could always be imitated by men"4), lecz także z trudności określenia momentu, w którym kopia stała się faksymile. Nie chodzi tu bowiem o zwielokrotnianie konkretnego egzemplarza (co miało miejsce w wypadku zastosowania drzeworytu, druku, ale też odlewnictwa i pieczęci ${ }^{5}$ ), ani także ,podrabianie” wydawnictw w postaci pirackich wydań (choć z perspektywy historii książki tworzenie falsyfikatów jest „o krok” od sporządzania faksymiliów). Według Karla Dachsa najwcześniejszym pełnym faksymile był sporządzony przez Senefeldera w 1808 roku „przedruk” tak zwanego Kalendarza Tureckiego — jednego z pierwszych druków Gutenberga $^{6}$. Z kolei w Lexikon des gesamten Buchwesens ${ }^{7}$ można znaleźć informację, że za najstarsze faksymile uchodzi 25 stron Martylologium Hieronymanum w miedziorycie Balthasara Moretusa z lat 1626-1633, a Janusz Sowiński datuje

${ }^{1}$ F. Unterkircher, Original und Faksimile als bibliophile Sammelobjekte, [w:] Beiträge zur Buchkunde und Kulturgeschichte: Festgabe für Franz Unterkircher zum 80. Geburtstag, red. O. Mazal, Graz 1984, s. 13; zachowano pisownię autora.

2 T. Hilka, Zur Terminologie und Geschichte der Faksimilierung, „Bibliothek Forschung und Praxis" 9, 1985, nr 3, s. 290. Autor powołuje się na dzieło Thomasa Fullera History of the Worthies of England z 1662 roku. Samo słowo (niekoniecznie w omawianym kontekście) było wykorzystywane już na przełomie XVI i XVII wieku, o czym może świadczyć wyszukiwanie w bazie Early English Books Online - wyrażenie (choć nie w omawianym kontekście) pojawia się choćby w tekście The Cobbler's Prophecy Roberta Wilsona z 1594 roku.

3 J.H. Campe, Wörterbuch zur Erklärung und Verdeutlichung der unserer Sprache aufgedrungenen fremde Ausdrücke, Braunschweig 1813, s. 308, cyt. za: T. Hilka, op. cit., s. 290.

4 ,Zasadniczo dzieło sztuki zawsze było możliwe do odtworzenia. Wykonane przez człowieka artefakty zawsze mogły być przez człowieka skopiowane" - W. Benjamin, The work of art in the age of mechanical reproduction, [w:] Illuminations, red. H. Arendt, New York 1969, s. 2, https://web.mit.edu/allanmc/www/benjamin.pdf [dostęp: 21.07.2019]; jeżeli nie podano inaczej, przeł. P.K.

5 Benjamin pisze: „The Greeks knew only two procedures of technically reproducing works of art: founding and stamping" - ibidem.

${ }^{6}$ K. Dachs, Die Konzeption von Faksimileausgaben als bibliothekarische Aufgabe, „Bibliotheks-Forum Bayern: BFB” 14, 1986, nr 1, s. 36.

${ }^{7}$ Faksimile-Ausgaben, [w:] Lexikon des gesamten Buchwesens, T. 2, red. S. Corsten, G. Pflug, F.A. Schmidt-Künsemüller, Stuttgart 1989, s. 538-539. 
„początki edytorstwa faksymilowego w Polsce” na pierwszą ćwierć XIX wieku W literaturze podawane są również inne przykłady pierwszych faksymiliów.

Sama idea tworzenia dokładnych kopii obiektu nierozłącznie wiąże się z techniką ich sporządzenia. W ciągu dziejów opracowywano zatem różne sposoby powielenia obrazu i tekstu. Podstawową metodą było ręczne przerysowywanie interesujących fragmentów, czasem całych kodeksów. Do podobnych celów oraz w podobny sposób wykorzystywano drzeworyt i miedzioryt. Mającym odzwierciedlenie w ilości, jakości oraz skali przedsięwzięć związanych ze sporządzaniem faksymiliów przełomem było wykorzystanie litografii (wraz z homografią, to jest wariantem tej techniki opracowanej przez Adama Pilińskiego ${ }^{9}$ ). Ukoronowaniem tych wysiłków stało się upowszechnienie i wykorzystanie fotografii przy reprodukcji, co w XX wieku zaowocowało niespotykanym dotąd wzrostem produkcji faksymiliów ${ }^{10}$. Obecnie wykorzystuje się zaawansowane możliwości skanerów oraz druku, także w technologii 3D. Na marginesie tych rozważań należy powiedzieć, że faksymile pozostaje nim bez względu na technikę wykonania — o ile rozpatrujemy dany przykład we właściwym mu kontekście historycznym. To oznacza, iż pojęcie faksymiliów ewoluuje w czasie, jednak nawet współcześnie nie traci nic ze swej idei.

Również w XX wieku reprinty i faksymilia stały się przedmiotem dyskusji w środowisku naukowym oraz wśród wydawców i księgarzy. Szczególnie to drugie środowisko (z oczywistych zresztą względów) aktywnie w tej dyskusji uczestniczyło. Jednym z ciekawszych głosów był artykuł Edwarda Rylukowskiego ${ }^{11}$, który nie tylko przeanalizował sytuację na polskim rynku w latach 70 . XX wieku, lecz także odniósł się do trendów obecnych w innych państwach europejskich. Ówczesnym wyzwaniem dla pracowników książki polskiej było zorganizowanie produkcji „reprintów”, określenie priorytetów i planów wydawniczych. W obliczu strat wojennych polskich bibliotek, a także możliwości, które otwierały się przed taką formą książki, dostrzegano potrzebę podjęcia konkretnych działań. W tym celu pod auspicjami ministra kultury i sztuki powstała grupa, która miała opracować koncepcję tego przedsięwzięcia. Powołano Radę Programową, składającą się z przedstawicieli środowisk księgarskich, antykwariatów, bibliotek oraz środowiska naukowego i znawców przedmiotu, za wydanie zaś miały odpowiadać Wydawnictwa Artystyczne i Filmowe.

Znacznie później pojawił się (raczej jako głos w dyskusji) artykuł Janusza Tazbira $^{12}$, następnie - niejako podsumowujące dotychczasowy dorobek, ale też omawiające zagadnienie faksymiliów w XXI wieku — prace Tomasza Kozielca

8 J. Sowiński, Między oryginatem, kopia a falsyfikatem: polskie edycje faksymilowe, Kraków 2009, s. 48.

${ }^{9}$ Ibidem, s. 223.

10 Ibidem, rozdz. W kręgu techniki i technologii.

11 E. Rylukowski, Nowe życie starych ksiag - reprinty, „Księgarz” 20, 1976, nr 3, s. 12-24.

12 J. Tazbir, W królestwie reprintów, wznowień i - nieporozumień, „Wiadomości Historyczne" 1997 , nr 2, s. 122-126. 
i Barbary Centek ${ }^{13}$. Wielokrotnie problematyką tą zajmował się Janusz Sowiński, który opublikował liczne artykuły w czasopismach naukowych i fachowych, których zwieńczeniem była książka ${ }^{14}$ wydana w 2009 roku. Mimo że pojawiło się również kilka pokrewnych artykułów, można powiedzieć, że w polskim piśmiennictwie temat ten nie został wyczerpany.

Inaczej rzecz się ma choćby w krajach niemieckojęzycznych, gdzie podejmowanie zagadnienia faksymiliów (zwłaszcza od lat 70. XX wieku) pozwoliło na stworzenie mocnych podstaw do kolejnych badań. Szczególnie warto wymienić tu takich autorów, jak Karl Dachs, Thomas Hilka, Manfred Kramer, Franz Unterkircher czy Hans Zotter. Omówienie poglądów wymienionych autorów można także znaleźć w pracy Petera Barkefelda ${ }^{15}$. Pojawiają się ponadto, zwłaszcza obecnie, prace w języku angielskim (niektóre zostały wymienione w bibliografii), a wiele informacji można znaleźć także na stronach wydawnictw faksymiliów oraz serwisów pokrewnych. Krótkie, acz treściwe omówienia opublikowano również w zagranicznych encyklopediach bibliologicznych.

\section{POJĘCIE „FAKSYMILE” W OPRACOWANIACH ZAGRANICZNYCH}

Definicje faksymile oraz pojęć pokrewnych, mimo iż obecne w wielu encyklopediach dziedzinowych, nie są zbieżne we wszystkich aspektach. Podobnie jak w języku polskim denotują one różne znaczenia, zależne od techniki wykonania, przeznaczenia czytelniczego czy (przede wszystkim) wierności oryginałowi. I tak w języku angielskim pojawiają się takie pojęcia, jak facsimile edition, facsimile, w języku francuskim - fac-similé, w języku czeskim — faksimilie, w języku chorwackim — faksimil, faksimilna reprodukcija. Najwięcej pojęć związanych z faksymile pojawia się w języku niemieckim, w encyklopediach występują bowiem takie hasła, jak Faksimile, Faksimile-Ausgaben, Faksimiledruck, a nawet Faksimilierung. Niezależnie od nich funkcjonują również pojęcia typu reprint (ang.) czy też Nachdruck (niem.), te jednak, choć pokrewne, nie są tożsame z wymienionymi.

The Oxford Companion of the Book definiuje facsimile edition jako

a documentary edition that reproduces a text precisely, duplicating its linguistic features (e.g. spelling, punctuation) along with some of its bibliographical features (e.g. typography, spacing). Unlike critical editions, facsimile editions present a text as it is, leaving in place whatever peculiarities and errors lie therein ${ }^{16}$.

13 B. Centek, T. Kozielec, Faksymile i reprinty — sposób na zachowanie słowa drukowanego i pisanego, cz. 1, „Świat Druku”2009, nr 10, s. 21-24; zob. też B. Centek, T. Kozielec, Faksymile i reprinty - sposób na zachowanie słowa drukowanego i pisanego, cz. 2, „Świat Druku” 2009, nr 12, s. $21-24$.

14 J. Sowiński, op. cit.

15 P. Barkefeld, Faksimile im Insel Verlag, München 2002.

16 „Edycja dokumentalna, która dokładnie odwzorowuje tekst, powielając jego cechy językowe (na przykład pisownię, interpunkcję) wraz z niektórymi cechami bibliograficznymi (na 
W haśle wyróżnione są dwa typy faksymile: photofacsimile oraz type facsimile. Photofacsimile rozumiane jest jako dokładne odtworzenie dokumentu, obejmujące swym zakresem zarówno mikrofilmowanie, jak i wysokiej jakości edycje drukowane. Type facsimile nie jest dokładną reprodukcją dokumentu, lecz odzwierciedla jego strukturę, taką jak układ marginaliów, glos interlinearnych, interpunkcji, czasem też kroju pisma (to jednak nie występuje na przykład w wypadku rękopisów). Jest to jednak forma bardziej czasochłonna i skomplikowana, wymaga bowiem opracowania i edycji (między innymi porównania kilku wersji oryginału).

Jedna z obszerniejszych definicji niemieckich podaje, że faksymile to

die drucktechnische Wiedergabe einer unikalen oder gedruckten Vorlage d.h. eines Handschrift, eines Drucks - egal ob. Einzelblatt oder Buch, unter Verzicht auf manuelle Eingriffe (Goldauflagen, Einbände oder Replikate des Orginals) ${ }^{17}$.

I w niej jednak pojawia się rozróżnienie między Voll-Faksimile (to jest pełnym faksymile) a Teil-Faksimile (to jest częściowym faksymile), przy czym kryterium podziału odnosi się albo do zakresu edycji (całości lub tylko fragmentu oryginału), albo sposobu edycji (jego wierności kolorystycznej). Samo ukształtowanie wydania (papier, oprawa, zdobienia) jest już częściowo „kwestią smaku” wydawcy.

Ciekawym terminem jest też Faksimilierung, co oznacza samą produkcję faksymile lub jej przebieg. Podobnie jak w języku polskim często powstają również terminy bliskoznaczne, na przykład Faksimile-Editionen, Faksimile-Ausgaben.

Na uwagę zasługuje definicja zawarta w PN-ISO 5127:2005 ${ }^{18}$. Określa ona faksymile w sposób następujący: ,,reprodukcja, która jest podobna do dokumentu oryginalnego tak bardzo, jak to możliwe, pod względem zawartości, formy i wyglądu, ale niekoniecznie o tych samych rozmiarach". Trudno powiedzieć, dlaczego właśnie rozmiar stanowi wyjątek od konieczności wiernej reprodukcji. Być może wynika to z ograniczeń współczesnych norm poligraficznych lub różnorodności formatów oryginalnych.

Analizując różne definicje, można zauważyć, że pokrywają się one na kilku płaszczyznach. Wszyscy autorzy zgadzają się, iż powstała kopia ma być „,możliwie wierną" reprodukcją oryginału. Spór pojawia się dopiero w momencie ustalenia elementów, które powinny zostać odtworzone (mowa o tym w dalszej części artykułu). Większej roli nie odgrywa również technika powielenia, jednak wraz

przykład typografia, odstępy). W przeciwieństwie do edycji krytycznych edycje faksymilowe przedstawiają tekst takim, jakim jest, pozostawiając jakiekolwiek istniejące w nim błędy i cechy szczególne" - Facsimile edition, [w:] Oxford Companion of the Book, T. 2, red. M.F. Suarez, S.J. i H.R. Woudhuysen, Oxford 2010, s. 712.

17 „Odtworzenie za pomocą technik drukarskich unikalnego lub wydrukowanego wzoru, to jest rękopisu, druku - obojętnie, czy jest to pojedyncza karta, czy druk, przy rezygnacji z zabiegów manualnych (złoceń, oprawy lub replik oryginału)" - Faksimile, [w:] Lexikon der Medienund Buchwissenschaft, T. 1, red. T. Keiderling, Stuttgart 2016, s. 249.

18 PN-ISO 5127:2005, Informacja i dokumentacja - Terminologia. 
z rozwojem urząazeń poligraficznych starsze, mniej doskonałe techniki reprografii i druku zostały zastąpione przez nowe, oferujące większą dokładność w odtwarzaniu kształtów i kolorów. W wielu hasłach pojawia się także historia zjawiska oraz technik reprodukcji.

\section{FAKSYMILE — WIELE TERMINÓW, TO SAMO POJĘCIE?}

Problemy ze zdefiniowaniem i odróżnieniem faksymile od innych typów reprodukcji można złożyć na karb chaosu i bogactwa różnych (używanych często niekonsekwentnie) terminów. Reprodukcja, wydanie fotooffsetowe, przedruk, edycja faksymilowa, reprint, wydanie fototypiczne - to tylko kilka z wielu określeń stosowanych w literaturze oraz różnych środowiskach zawodowych. Jak zauważył J. Sowiński ${ }^{19}$, można jednak dostrzec pewne prawidłowości, które determinują tworzenie i wykorzystanie wymienionych określeń.

Po pierwsze, część terminów odwołuje się do technologii, z których pomocą reprodukcja została wykonana — tu można zaliczyć takie terminy, jak wydanie fotooffsetowe, wydanie fototypiczne itp. Drugą grupę tworzą nazwy niezwiązane z techniką wytworzenia, lecz raczej z funkcją lub charakterem obiektu - do tej grupy należą takie określenia, jak faksymile, reprodukcja, reprint ${ }^{20}$ czy po prostu kopia. Warto zaznaczyć, że terminy ściśle powiązane z metodą wykonania są od niej zależne i jako takie nie są w pełni uniwersalne. Mogą stanowić więc raczej funkcję dookreślenia konkretnego wydania, lecz wątpliwe wydaje się ich wykorzystanie ogólne. Kwestia użycia terminów z grupy drugiej jest także problematyczna, nie są one bowiem na tyle ostre, aby jednoznacznie (i bez budowania kolejnych typologii) określić typ danego dokumentu.

Po drugie, niektóre terminy są chętniej wykorzystywane przez różne środowiska (głównie wydawców i naukowców). Wydaje się, iż termin reprint oraz określenia związane z techniką powielenia częściej wykorzystywane są przez środowisko wydawców, a z terminu faksymile chętniej korzystają księgoznawcy, bibliofile i naukowcy (choć i tu bywa różnie) ${ }^{21}$. Wyszukiwanie przeprowadzone za pomocą wyszukiwarki korpusowej PELCRA ${ }^{22}$ pokazuje, że wyraz „reprint” jest nieco popularniejszy od ,faksymile”. Reprint w Narodowym Korpusie Języka Polskiego pojawia się 59 razy w 42 tekstach, faksymile zaś — 46 razy w 34 teks-

19 J. Sowiński, op. cit., s. 12.

20 Zaliczenie terminu ,reprint” do drugiej grupy może budzić wątpliwości. Określenie to nie wskazuje jednak bezpośrednio na technikę powielenia (przynajmniej w sposób oczywisty), lecz raczej na fakt, iż coś zostało ,ponownie wydrukowane”.

${ }^{21}$ B. Centek, T. Kozielec, op. cit. cz. 1, s. 21.

22 Narodowy Korpus Języka Polskiego, http://www.nkjp.uni.lodz.pl/ [dostęp: 22.07.2019]. 
tach. Trzeba także wspomnieć, że kilka razy określenie faksymile wystąpiło jako reprodukcja podpisu w postaci pieczątki, co de facto jeszcze bardziej ogranicza wyniki wyszukiwania. Definicje kopii i reprodukcji są zbyt szerokie; ich definiens może odwoływać się również do reprodukcji dzieł sztuki, obiektów, technik itp. $\mathrm{O}$ ile nie stanowi to problemu, kiedy definicja jest powiązana z obiektem, o tyle wykorzystanie tych wyrazów jako terminów wyszukiwawczych będzie skutkować dużą ilością nierelewantnych wyników.

\section{FAKSYMILE A REPRINT}

Niewątpliwie w pragmatyce edytorskiej i bibliotekarskiej najwięcej kłopotów sprawia jednoznaczne określenie, czy dany dokument jest reprintem, czy faksymile. Rozróżnienie to często wykonywane jest intuicyjnie, jednak nie zawsze prawidłowo. Nic w tym dziwnego, nawet definicje encyklopedyczne nie zawsze jasno wyjaśniają różnice między tymi obiektami, co byłoby przydatne zwłaszcza przy wydawnictwach znajdujących się niejako „na krawędzi” obu pojęć. Poniżej przedstawiono różne definicje faksymile i reprintu, pochodzące z tych samych, wybranych źródeł.

Tab. 1. Wybrane definicje faksymile i reprintu

\begin{tabular}{|l|l|l|}
\hline \multicolumn{1}{|c|}{ Źródło } & \multicolumn{1}{|c|}{ Definicja faksymile } & \multicolumn{1}{c|}{ Definicja reprintu } \\
\hline $\begin{array}{l}\text { Słownik wydawcy, oprac. } \\
\text { Barbara Kalisz, Warszawa }\end{array}$ & $\begin{array}{l}\text { Faksymile - (1) dokładna } \\
\text { kopia (reprodukcja) podpisu, } \\
\text { rękopisu, dokumentu, } \\
\text { rysunku, sporządzona ręcznie, } \\
\text { mechanicznie, fotograficznie; } \\
\text { (2) klisza lub pieczątka } \\
\text { odtwarzająca podpis }\end{array}$ & $\begin{array}{l}\text { Reprint - wierna } \\
\text { fotoreprodukcja wydania } \\
\text { oryginalnego, zaopatrzona } \\
\text { dodatkowo przez wydawcę } \\
\text { w kartę tytułową i okładkę }\end{array}$ \\
\hline $\begin{array}{l}\text { Podręczny słownik } \\
\text { bibliotekarza, oprac. Grzegorz } \\
\text { Czapnik, Zbigniew Gruszka } \\
\text { przy współpracy Hanny } \\
\text { Tadeusiewicz, Warszawa 2011 }\end{array}$ & $\begin{array}{l}\text { Faksymile - wierna } \\
\text { podobizna dokumentu } \\
\text { rękopiśmiennego lub } \\
\text { drukowanego, sporządzona } \\
\text { odręcznie (odrys), } \\
\text { mechanicznie bądź }\end{array}$ & $\begin{array}{l}\text { Reprint - 1. Przedruk } \\
\text { fotomechaniczny druku, } \\
\text { często mniej dokładne } \\
\text { faksymile, od którego } \\
\text { niewymagane jest } \\
\text { podrabianie papieru, } \\
\text { pieczątka imitująca podpis }\end{array}$ \\
& & $\begin{array}{l}\text { sposobu oprawienia itd. } \\
\text { 2. Fotoreprodukcja oryginału, } \\
\text { którą wydawca zaopatrzył } \\
\text { w nowe dane wydawnicze - } \\
\text { kartę tytułową, okładkę }\end{array}$ \\
& & i informacje o przedruku. \\
\hline
\end{tabular}




\begin{tabular}{|l|l|l|}
\hline $\begin{array}{l}\text { Stownik języka polskiego PWN } \\
\text { (online) }\end{array}$ & $\begin{array}{l}\text { Faksymile, facsimile [wym. } \\
\text { faks-imile] - 1. dokładna } \\
\text { reprodukcja dokumentu, } \\
\text { rysunku lub podpisu; } \\
\text { 2. pieczątka lub klisza } \\
\text { odtwarzające własnoręczny } \\
\text { podpis; 3. system }\end{array}$ & $\begin{array}{l}\text { Reprint - nowe wydanie } \\
\text { książki będące wierną kopią } \\
\text { oryginału, wykonane bez } \\
\text { powtórnego składania tekstu }\end{array}$ \\
& $\begin{array}{l} \\
\text { telekomunikacji służący } \\
\text { do przesyłania obrazów } \\
\text { nieruchomych i ich odbioru } \\
\\
\text { w postaci utrwalonej }\end{array}$ \\
\hline
\end{tabular}

Źródło: opracowanie własne.

Jak widać, samo kryterium podobieństwa względem oryginału jest niewystarczające. Paradoksalnie, definicja reprintu z Podręcznego stownika biblioteka$r z a$ wnosi najwięcej, ponieważ mimo dość swobodnego sformułowania „mniej dokładne faksymile" dopełnia "od którego niewymagane jest podrabianie papieru, sposobu oprawienia itd.”. Wyłuskać można dzięki temu pierwszą różnicę: faksymile jest dokładniejsze niż reprint — nie tylko pod względem druku, lecz także wszystkich elementów morfologicznych książki, głównie papieru i oprawy. Kolejnym istotnym elementem są wspomniane „nowe dane wydawnicze”, czyli karta tytułowa, okładka i informacja o przedruku. Nie wspomniano tutaj o stronie redakcyjnej, w którą współcześnie zaopatrywane są zarówno reprinty, jak i faksymilia. Najostrzejszym kryterium jest jednak informacja, którą wydawca zamieszcza w książce, typu ,reprint wydania z ... roku”, ,przedruk z ...” itp. Jest to praktyka pożądana, choć nie we wszystkich przypadkach stosowana, na ogół słusznie określająca typ dokumentu.

Niestety żadna z podanych definicji nie rozróżnia tych dokumentów ze względu na kryteria funkcjonalne. Ich uwzględnienie pozwoliłoby na dookreślenie i dopełnienie wskazanych terminów. Funkcje i recepcja faksymiliów i reprintów różnią się, co przekłada się na określone cechy. Reprint powstaje, aby zaspokoić popyt na pozycję, której nakład się wyczerpał, nie była wznawiana lub przeszła do domeny publicznej. Ze względu na możliwości poligraficzne można powielić wydanie niskim kosztem, nie wymaga bowiem ono ponownego składu oraz szczegółowej redakcji, ograniczającej się czasem do wstępu oraz nowej strony redakcyjnej. Reprinty charakteryzują się zatem najczęściej stosunkowo wysokimi nakładami przy niskiej cenie wytworzenia. Faksymile przeciwnie - wydawane jest raczej dla wąskiego grona odbiorców, produkcja zaś niesie z sobą wysokie koszty, a więc i cenę. Sporządzane jest nie tylko na podstawie wydania drukowanego, lecz także rękopisów, starodruków, muzykaliów. Widać zatem, że zarówno dokument pierwotny, jak i grono odbiorców w wypadku faksymiliów są bardziej wyspecjalizowane, co wpływa także na nakład i cenę. Kwestia wierności omówiona wcześniej dopełnia charaktery- 
styki obu dokumentów. Zrozumiałe jest też, iż taka analiza nie zawsze jest możliwa ze względu na przenikanie się funkcji i brak ostrych granic w tym podziale.

Również katalogowanie i wyszukiwanie faksymiliów z perspektywy zasobów bibliotecznych może nastręczać wielu trudności. Teoretycy i praktycy bibliotekarstwa wraz z kolejnymi zasadami katalogowania doskonalili reguły opisu faksymiliów i innych form reprodukcji dokumentów, takich jak mikroformy. Ów proces opisał Steven A. Knowlton ${ }^{23}$, poczynając od zasad katalogowania Cuttera, przez format AACR2, po omówienie zależności między oryginałem a reprodukcją w modelach FRBR i RDA. Właśnie w RDA reprodukcje plasuje się jako related manifestations, do opisu relacji zaś służy termin equivalent manifestation ${ }^{24}$. Jest to nawiązanie do terminologii FRBR, w której materializacja (manifestation) oznacza (upraszczając) materialną formę dzieła, na przykład wydanie ${ }^{25}$. Celem RDA jest zatem wytworzenie bibliograficznego połączenia (czy też zależności), które ukazywałyby związek dzieła oryginalnego z jego różnymi materializacjami (to jest poszczególnymi reprodukcjami, edycjami i wydaniami).

Przy tej okazji warto również wspomnieć o najważniejszych źródłach informacji dotyczących faksymiliów. Pierwszym z nich jest Bibliographie faksimilierter Handschriften, autorstwa Hansa Zottera, która ukazała się w postaci dwóch wydań (Graz 1976 i 1992) oraz na dyskietkach (1996), obecnie jednak istnieje również w postaci bazy danych na stronie internetowej ${ }^{26}$. Została ona opracowana na podstawie zbiorów faksymiliów francuskiej i austriackiej biblioteki narodowej oraz Biblioteca Apostolica Vaticana ${ }^{27}$. Wydanie drugie znacząco wzbogaciło korpus publikacji, niemal podwajając liczbę zarejestrowanych faksymiliów ${ }^{28}$.

Wyszukiwanie w bazie odbywa się poprzez wybór lokalizacji dokumentu oryginalnego (to jest podstawy dla faksymile). Pod opisem dokumentu pierwotnego znajdują się opisy reprodukcji. Autor w przedmowie do kolejnych wydań wyjaśnił (choć nie zawsze precyzyjnie) sposób selekcji i prezentacji opisów. $\mathrm{Na}$ stronie prócz bibliografii znajdują się przedmowy do obu wydań, bibliografia przedmiotu (Literaturverzeichnis), lista serii wydawniczych, wykaz skrótów oraz trzy diagramy obrazujące przyrost produkcji faksymiliów w XX wieku.

Z kolei informacje o najnowszych faksymiliach można znaleźć w serwisie Facsimile Finder ${ }^{29}$. Oferuje on bogate możliwości wyszukiwania, co pozwala na

23 S.A. Knowlton, How the current draft of RDA addresses the cataloging of reproductions, facsimiles, and microforms, „Library Resources \& Technical Services” 53, 2009, nr 3, s. 159-165.

24 Ibidem, s. 163.

25 A. Filipek, Model opisu dokumentu wedtug FRBR (Functional requirements for bibliographic record), „Zagadnienia Informacji Naukowej” 2005, nr 2, s. 18.

${ }^{26}$ H. Zotter, Bibliographie faksimilierter Handschriften (Internet Ausgabe), http://sosa2.unigraz.at/sosa/faksbib/index.php [dostęp: 23.07.2019].

27 Ibidem, das Vorwort zur 1. Auflage.

28 Ibidem, das Vorwort zur 2. Auflage.

29 Facsimile Finder, https://www.facsimilefinder.com/ [dostęp: 29.01.2018]. 
wszechstronne przeszukiwanie zasobu liczącego ponad 1200 faksymiliów (sensu stricto). Nieocenioną wartością dodaną są również zdjęcia i filmy prezentujące obiekty, a także zintegrowany z bazą blog popularyzujący omawianą tematykę. Mimo istnienia serwisów konkurencyjnych Facsimile Finder wydaje się najbogatszym źródłem dopełniającym wspomnianą bibliografię Zottera.

\section{PRÓBY TYPOLOGII}

Pomijając artykuły problemowe pojawiające się na gruncie polskim już od połowy XX wieku, większość współczesnych rozważań nad faksymiliami na gruncie polskim stanowi pokłosie książki Jana Sowińskiego Między oryginatem, kopia a falsyfikatem. Polskie edycje faksymilowe oraz działalności wydawnictw specjalizujących się w wykonywaniu faksymiliów. O ile sam Sowiński wskazał na mnogość i nieprecyzyjność terminów oznaczających różne rodzaje reprodukcji, o tyle nie ujednoznacznił i nie uporządkował zastanego nieładu terminologicznego $^{30}$. Wyróżnił jedynie re print jako niedokładną kopię oryginału zaopatrzoną w dodatkową kartę tytułową, edycję faksy milową, która różni się od reprintu dodaniem komentarza i aparatu naukowego, i wreszcie wierną reprodukcję dokumentu oryginalnego - facs imile $e^{31}$.

W odpowiedzi na propozycję Sowińskiego Grzegorz Nieć stworzył własną typologię:

1. Naukowa edycja faksymilowa, zawierająca oprócz reedycji danego dzieła (manuskryptu, druku, dokumentu) transkrypcję i rozbudowany aparat naukowy, gdzie kopia danego wydania jest jedynie częścią szeroko zakrojonego przedsięwzięcia; 2 . Reprint wzbogacony jedynie mniejszym lub większym komentarzem, wstępem, glossą; 3 . Reprint będący kopią wiernie naśladującą oryginał, bez jakichkolwiek dodatków; 4. Kolejne wydania dzieła za pomocą techniki fotooffsetowej z nową stroną tytułową, okładką; Wreszcie swego rodzaju hybrydy łączące w jedną całość reprodukcje dawnych wydań i teksty złożone na nowo, połączone wspólną paginacją, indeksami ${ }^{32}$.

Podział ten, choć dosyć dobrze oddaje aktualne zróżnicowanie istniejących wydań, wydaje się nazbyt szczegółowy. I nic dziwnego, kontaminacja kryteriów estetyczno-wydawniczych (wierność odwzorowania oryginału) oraz edytorskich (obecność komentarza, strony tytułowej, aparatu naukowego) utrudnia ścisłe rozróżnienie faksymiliów. Nieco precyzyjniejsze są typologie niemiecka (Voll-i Teil-Faksimile) oraz angielska (photo- i type facsimile), które odwołują się głównie do wizualnej wierności dokumentu. Analizując możliwe stopnie szczegółowości w odwzorowaniu oryginału, można wyróżnić grupy zawarte w tabeli 2.

${ }^{30} \mathrm{Na}$ problem ten wskazał również Grzegorz Nieć w swoim artykule $O$ reprintach uwag kilka, „Annales Universitatis Paedagogicae Cracoviensis” 2010, s. 84.

31 J. Sowiński, op. cit., s. 13-16.

32 G. Nieć, op. cit., s. 87. 
Tab. 2. Typologia faksymiliów ze względu na wierność odwzorowania oryginału

\begin{tabular}{|c|c|c|}
\hline $\begin{array}{c}\text { Podział ze względu } \\
\text { na stopień szczegółowości }\end{array}$ & Cechy reprodukcji & Przykłady \\
\hline $\begin{array}{l}\text { Grupa I (reprinty)* — niska } \\
\text { dokładność odwzorowania } \\
\text { * dotyczy dokumentów wyko- } \\
\text { nanych metodami druku (rę- } \\
\text { kopisy itp. mogą być określane } \\
\text { jako faksymile sensu largo) }\end{array}$ & $\begin{array}{l}\text { — odwzorowanie układu } \\
\text { tekstu, kroju pisma } \\
\text { — druk czarno-biały }\end{array}$ & $\begin{array}{l}\text { — reprinty } \\
\text { — niskiej jakości faksymilia } \\
\text { — niektóre edycje źródłowe }\end{array}$ \\
\hline $\begin{array}{l}\text { Grupa II (faksymile sensu } \\
\text { largo) — średnia dokładność } \\
\text { odwzorowania }\end{array}$ & $\begin{array}{l}\text { — druk kolorowy — odwzoro- } \\
\text { wanie kolorów (niedokładne) } \\
\text { — zachowany format doku- } \\
\text { mentu pierwotnego (rękopisu, } \\
\text { starodruku) lub format podobny } \\
\text { — struktura papieru (na przy- } \\
\text { kład ślady żeberek) odwzoro- } \\
\text { wana za pomocą wydruku } \\
\text { — odwzorowanie układu teks- } \\
\text { tu, kroju pisma }\end{array}$ & $\begin{array}{l}\text { — wysokonakładowe faksy- } \\
\text { milia } \\
\text { — część edycji źródłowych }\end{array}$ \\
\hline $\begin{array}{l}\text { Grupa III (faksymile sensu } \\
\text { stricto) — wysoka dokład- } \\
\text { ność odwzorowania }\end{array}$ & $\begin{array}{l}\text { — rekonstrukcja zdobień: rub- } \\
\text { rykowania, inicjałów, złoceń } \\
\text { - rekonstrukcja ubytków } \\
\text { w bloku, urwanych/uciętych } \\
\text { fragmentów kart, przeszyć } \\
\text { (pergaminu) } \\
\text { - oprawa zbliżona do oprawy } \\
\text { oryginalnej (introligatorska), } \\
\text { plecione kapitałki, zrekonstru- } \\
\text { owane wyklejki (na przykład } \\
\text { marmurki) } \\
\text { — wykorzystanie do produkcji } \\
\text { papieru imitującego materiał } \\
\text { oryginalny/pergaminu (użycie } \\
\text { papieru żeberkowego, czerpa- } \\
\text { nego, pergamenatu itp.) } \\
\text { - uwzględnienie cech } \\
\text { charakterystycznych orygina- } \\
\text { łu: przebarwień, zabrudzeń, } \\
\text { znaków proweniencyjnych, } \\
\text { marginaliów } \\
\text { — zachowany format doku- } \\
\text { mentu pierwotnego (rękopisu, } \\
\text { starodruku) } \\
\text { — druk kolorowy - odwzoro- } \\
\text { wanie kolorów (dokładne) }\end{array}$ & $\begin{array}{l}\text { — faksymilia sensu stricto } \\
\text { — reprodukcje o charakterze } \\
\text { unikatowym (na przykład na } \\
\text { potrzeby ekspozycji) }\end{array}$ \\
\hline
\end{tabular}

Źródło: opracowanie własne. 
Nie można jednak całkowicie odciąć się od kryteriów „edytorskich”, dlatego powinny one zostać uwzględnione w wymienionych grupach jako element dodatkowy, precyzujący. W grupach I i II występuje dodatkowa strona tytułowa, podczas gdy komentarz, aparat naukowy, transkrypcja itp. stanowią całość wydawniczą (to jest są wydane jako jeden tom) z reprodukcją. W wypadku grupy III komentarz jest dodatkiem do faksymile, dołączanym w postaci odrębnego tomu. Bardziej szczegółowe rozróżnienie może zostać poczynione na gruncie tekstologii czy edytorstwa naukowego.

Warto wspomnieć jednak, że trudno nazywać kopię rękopisu reprintem. Termin ten kojarzy się bowiem z technologią druku (podobnie jak przedruk) i jako taki nie może być wykorzystywany nawet przy niedokładnym odwzorowaniu oryginału. Lepiej więc, w ramach wyjątku, określić taką kopię mianem faksymile sensu largo.

Zupełnie inny podział, skupiający się bardziej na funkcji niż formie dokumentu proponuje Cor Koeman ${ }^{33}$. Mimo że autor skupił się głównie na opisaniu kwestii reprodukcji map, stworzony przez niego podział dobrze określa również inne typy kopii. Jak pisze,

The purpose of publishing facsimiles of early maps and atlases varies. It may be any one of the following:

a. Imitation of the original, with the intention not of producing a forgery, but of making it look like a forgery.

b. Imitation of the original, retaining the quality of its colours and linework, but advertising it as a work of outstanding modem reproduction technique.

c. Monochrome reproduction of the essential content of the original, retaining its graphic quality, but mainly with the intention of serving scholars and students.

d. Reproduction of the original, only for reference, without aiming at any graphic quality ${ }^{34}$.

Jak widać, faksymilia można dzielić ze względu na różne kryteria - wierność, kryteria wydawnicze czy funkcję. Trudno jednak tworzyć typologiczne hybrydy, ponieważ może to prowadzić do mnożenia bytów oraz utrudniać przyporządkowywanie konkretnych już przykładów określonym kategoriom.

33 C. Koeman, An increase in facsimile reprints, „Imago Mundi” 18, 1964, s. 87-88.

34 „Cel publikowania faksymiliów wczesnych map i atlasów jest różny. Może to być którykolwiek z następujących:

a. imitacja oryginału, z zamiarem nietworzenia falsyfikatu, lecz zrobienie go tak, że wygląda jak falsyfikat;

b. imitacja oryginału zachowująca jakość jego barw i kreski, ale reklamowana jako owoc wyjątkowej, nowoczesnej techniki reprodukcji;

c. monochromatyczna reprodukcja podstawowej zawartości oryginału, zachowująca jego graficzną jakość, jednak przeważnie z zamiarem służenia naukowcom i studentom;

d. reprodukcja oryginału wyłącznie jako źródła, bez dążenia do [zachowania] jakiejkolwiek graficznej jakości”- ibidem, s. 87. 


\section{TYPOLOGIA TEMATYCZNA}

Opierając się na wynikach wyszukiwania za pomocą terminu „faksymile” i jego obcojęzycznych odpowiedników, warto pokusić się o krótkie omówienie typów dokumentów ze względu na ich treść (lub charakterystyczną, wypływającą z treści formę). Stosując duże uogólnienie, można wyróżnić kilka zakresów (tematów), w których obrębie sporządza się reprodukcje:

1. literatura humanistyczna i społeczna - dzieła wartościowe pod względem literackim, będące często materiałem badawczym w edytorstwie filologicznym. Mogą to być zarówno kopie autografów literackich, pierwszych (lub jedynych) wydań danego dzieła, notatki, dzienniki etc. Grupa ta obejmuje ponadto dzieła z zakresu polityki, filozofii itd.;

2. źródła historyczne — kopie kronik, herbarzy, akt prawnych itp.;

3. muzykalia - najczęściej kopie rękopiśmiennych zapisów rozpoznawalnych utworów tworzonych przez znanych kompozytorów, takich jak Chopin, Bach czy Mozart, dzieła dotyczące teorii muzyki itd.;

4. kartografia - kopie starych map i atlasów;

5. dzieła z zakresu nauk ścisłych i przyrodniczych — kopie rękopisów i starodruków dotyczących techniki, medycyny, matematyki, botaniki, a także militariów;

6. dzieła religijne - święte księgi (głównie Biblie), rozprawy teologiczne, księgi liturgiczne i dewocyjne, modlitewniki;

7. dzieła estetyczne - kopie dzieł dotyczących sztuki, architektury, mody;

8. varia - faksymilia dzieł wielotematycznych.

\section{FUNKCJONALNA KONCEPCJA FAKSYMILE}

Karol Głombiowski w artykule $O$ funkcjonalna koncepcję nauki o książe pisze:

Wydaje się, że nie ma dzisiaj dla nauki o książce innej drogi naukowego rozwoju jak empiryczna i teoretyczna rozbudowa jej aspektu socjologicznego. Przyjmując bowiem funkcję książki jako podstawową zasadę interpretacji, osiągniemy zrozumienie wszystkich procesów związanych z produkcją, obiegiem i użytkowaniem książki ${ }^{35}$.

Podążając śladem nestora polskiej bibliologii, należy określić drogę i funkcje, jakie pełni faksymile, oraz stopień jego autonomiczności względem oryginału.

Idea stworzenia wiernej reprodukcji dokumentu — bez względu na jego formę - może się pojawić w różnych środowiskach. Niewątpliwie obecnie w pierwszej kolejności należy wymienić wyspecjalizowanych wydawców, dla których

35 K. Głombiowski, O funkcjonalna koncepcję nauki o książce, „Studia o Książce” 1, 1970, s. 23. 
publikowanie faksymiliów jest źródłem utrzymania. W przeciwieństwie do podobnych przedsięwzięć podejmowanych przez instytucje non-profit taka działalność wydawnicza ma najczęściej charakter komercyjny.

Kolejną grupą, dla której faksymile ma ogromną — i powiązaną z działalnością zawodową - wartość, są szeroko rozumiani pracownicy książki, począwszy od bibliotekarzy (pracowników działów zbiorów specjalnych), przez archiwistów, konserwatorów papieru i skóry, po muzealników. To oni, obcując ze starymi manuskryptami, starodrukami i innymi dokumentami, mogą określić potrzebę „zfaksymilowania” danego obiektu ze względu na jego wartość, potrzebę ochrony bądź częstą ekspozycję. Na ogół podejmują współpracę ze specjalistami z branży digitalizacyjnej i poligraficznej — czasem jako inspiratorzy przedsięwzięcia, czasem jako konsultanci dbający o to, aby oryginał nie uległ zniszczeniu w trakcie sporządzania kopii. W swojej pracy Die Kozeption von Faksimileausgaben ${ }^{36}$ K. Dachs wskazywał na możliwość redagowania przez bibliotekarza (przynajmniej częściowo) komentarza, który dołącza się do faksymile. Często dysponuje on bowiem wiedzą na temat historii czy innych elementów oryginału.

Następną grupę interesów tworzą pracownicy naukowi, którzy ze względu na badania źródłoznawcze, edytorstwo filologiczne czy niezmienną aktualność niektórych dzieł zabiegają o sporządzenie wiernych kopii dzieł oryginalnych. Szczególne miejsce wśród tych nauk zajmuje paleografia, albowiem przedmiot badań wymusza konieczność pracy z oryginalną formą pisma. Do tego kręgu można też zaliczyć badaczy amatorów, którzy analizując stare dokumenty, nie zawsze mają możliwość i sposobność dotarcia do oryginałów. Faksymile jako typ dokumentu interesuje ich głównie ze względu na treść, a niekoniecznie dokładnie odwzorowaną formę.

Z pewnym zaskoczeniem można stwierdzić, że faksymilia nie cieszą się zbytnim zainteresowaniem bibliologów, co — biorąc pod uwagę specyfikę badań — można uznać za usprawiedliwione. Można przypuszczać, iż dzieje się tak dlatego, że faksymile łączy w sobie różne typy książek oraz nosi „łatkę” dokumentu wtórnego.

Wreszcie, najliczniejszym gronem odbiorców są ludzie, dla których liczy się forma reprodukcji, dokładność odwzorowania, bogactwo zdobień i oprawy, słowem - estetyczna i materialna wartość faksymiliów. Szczególnie w tym wypadku liczy się podobieństwo, ,aura” oryginału, albowiem jak pisze Dachs, „Sammler sind zumeist Echtheitsfetischisten" ${ }^{37}$. W tej grupie można dokonać kolejnego podziału na bibliofilów, którzy znają się również na „pozamaterialnej” wartości książki, oraz odbiorców przypadkowych. Ci ostatni mogą jako prominenci lub sponsorzy otrzymać faksymile jako upominek podczas oficjalnych spotkań, w dowód wdzięczności za mecenat itp. Mogą je także zakupić jako osobliwą lokatę kapitału bądź jako dowód prestiżu i wysublimowanego gustu. Paradoksalnie

\footnotetext{
${ }^{36}$ K. Dachs, op. cit., s. 49.

37 „Kolekcjonerzy są w większości fetyszystami autentyzmu” — ibidem, s. 38.
} 
to dzięki ostatniej z wymienionych grup działalność polegająca na wydawaniu faksymiliów staje się opłacalna, umożliwia bowiem zwiększenie (wciąż jednak limitowanego!) nakładu do liczby, która pozwoliłaby na pokrycie wysokich kosztów produkcji i wygenerowanie zysku. Należy jednak podkreślić, że wymienione środowiska są nieliczne, a sama działalność wydawnicza — wybitnie niszowa. Tak wąski i wyspecjalizowany krąg odbiorców wpływa na kanały dystrybucji i reklamy produktu.

\section{PRODUKCJA}

Początek prac związanych z produkcją faksymiliów wyznacza wytypowanie obiektu i nawiązanie kontaktu z instytucją (najczęściej biblioteką), która go przechowuje. Nietrudno domyślić się, że przedsięwzięcie stworzenia reprodukcji wymaga poruszenia i rozwiązania takich kwestii, jak ocena stanu zachowania dokumentu oryginalnego i rozważenie wykonania zabiegów restauracyjnych. Biorąc pod uwagę możliwości procesów digitalizacyjnych, najkorzystniejszym zabiegiem wydaje się skanowanie arkuszy po renowacji, jednak jeszcze przed zszyciem w blok. Wpływa to na jakość skanów i ogranicza konieczność wykonywania żmudnych poprawek, polegających na korekcie odkształceń spowodowanych przez wygięcie stron przy grzbiecie. Najczęściej jednak, ze względu na charakter obiektu, unika się jakichkolwiek ingerencji w jego strukturę, przez co samo skanowanie jest bardziej skomplikowane.

Już na początku należy podjąć kluczową decyzję: gdzie powinien być wykonywany cały proces digitalizacji? Naturalne obawy budzi założenie, że transport i skanowanie w siedzibie wydawcy może wiązać się z brakiem właściwego zabezpieczenia przed kradzieżą czy nieodpowiednimi warunkami fizykochemicznymi (na przykład fluktuacjami temperatury bądź wilgotności, nadmiernym promieniowaniem oświetlenia). W takim wypadku należy zapewnić nie tylko właściwy mikroklimat, lecz także ubezpieczyć obiekt na wypadek kradzieży czy zniszczenia. Jednocześnie jednak w przypadku pozostawienia obiektu w murach biblioteki (czy innej instytucji) dużej biegłości będzie wymagać zorganizowanie całego warsztatu „na miejscu”. O skali takiego przedsięwzięcia może świadczyć fakt, iż cały osprzęt wykorzystany do skanowania Biblii Gutenberga (B42) w Pelplinie ważył około 500 kilogramów ${ }^{38}$ ! Zapewnienie odpowiedniego pomieszczenia oraz infrastruktury stanowi zatem nie lada wyzwanie. O ile jednak faksymile wspomnianego inkunabułu było wykonywane w siedzibie wydawnictwa Bernardinum ${ }^{39}$, o tyle niektórzy wydawcy (na przykład Quaternio Verlag Luzern) całe wyposaże-

38 Biblia Gutenberga i jej polskie faksymile, oprac. J. Pirożyński, T. Serocki, J. Tondel, Pelplin 2004, s. 88.

39 Ibidem.

ROCZNIKI BIBLIOTECZNE

ROK LXIII, 2019

(C) for this edition by CNS 
nie umieszczają w macierzystej dla obiektu instytucji, dzięki czemu nie opuszcza on swojego miejsca, pracownicy biblioteczni lub muzealni zaś mogą służyć radą podczas wykonywania kopii. Umożliwia to utrzymanie wysokiej jakości faksymile, czym szczyci się sam wydawca ${ }^{40}$. Proces skanowania — w zależności od posiadanych urządzeń - bywa zróżnicowany i nie różni się nazbyt od powszechnie stosowanych praktyk przy digitalizowaniu zbiorów specjalnych. W wypadku reprodukcji należy jednak przeprowadzić właściwe pomiary (tak jak było w przypadku B42), na przykład przy pomocy spektrofotometru, próbnika barw; nie tylko podczas skanowania, lecz także wydruku. Aby nie zniszczyć cennego oryginału, umieszcza się go na szalkach/kołysce, która pozwala na wykonywanie fotografii bez uszkodzenia szycia i grzbietu.

Wykorzystanie nowoczesnych metod druku offsetowego czy cyfrowego umożliwia dokładne odwzorowanie oryginalnych barw na kartach wydruku. Wymaga to jednak wielokrotnego porównywania, korekt i akceptacji finalnego projektu przez specjalistów, a czasami na przykład także kustosza zbiorów. W tym przypadku nieocenionym narzędziem jest ludzkie oko, które z łatwością wychwyci niedoskonałości. Dodatkowym wyzwaniem jest uwzględnienie koloru i faktury materiału, na którym wydruk jest wykonywany. Sam dobór papieru, pergamenaty czy welinu w takim zakresie, aby odpowiadał parametrami materiałom, z których wykonany jest rękopis czy starodruk, wymaga niekiedy długich poszukiwań wykonawcy edycji i ustalenia odpowiednich parametrów (gramatury, grubości kart - na przykład uśrednionej). Dobrze dobrany materiał wraz z fakturą, grubością i haptycznym podobieństwem przydaje reprodukcji autentyczności. Kolejnym zabiegiem jest odtworzenie złoceń; najczęściej wykorzystuje się odpowiednią farbę, choć tę łączy się czasem ze złotą folią. Oczywiście możliwe są też złocenia manualne, to jednak znacząco wydłuża proces produkcji. Mimo to nie jest to rzadka praktyka, zwłaszcza w wypadku ekskluzywnych, szczegółowo dopracowanych faksymiliów kodeksów średniowiecznych. Podobnie wysokie wymagania stawia się podczas samego procesu drukowania, a manualne „dopieszczenie” łączy faksymile bardziej z książką artystyczną niż masową.

Ukoronowaniem prac nad faksymile jest jego oprawienie — należy oddać arkusze w ręce doświadczonego introligatora-artysty (czy — biorąc pod uwagę skalę projektu - całej pracowni introligatorskiej), który wykorzystując dostępne narzędzia, wykona właściwe oprawy. Mogą być one wzorowane na oprawach z epoki, odwzorowywać oprawę egzemplarza, na podstawie którego wykonywano faksymile ${ }^{41}$, bądź stanowić jedynie ,stylizowaną” oprawę współczesną ${ }^{42}$. Jest

${ }^{40}$ Herstellung: Die Kunst der Faksimilierung, Quaternio Verlag Luzern, https://quaternio. ch/herstellung-faksimilierung/ [dostęp: 23.07.2019].

${ }^{41}$ Nie jest to jednoznaczne z oprawą oryginalną, ponieważ często stare kodeksy były przeoprawiane - w ten sposób XIV-wieczny kodeks mógł mieć oprawę z XVIII wieku.

42 Niektóre faksymilia mają różne warianty opraw. Liber Precum wydana przez Akademische Druck- u. Verlagsanstalt (ADEVA) ma dwa warianty oprawy: skórzaną (tradycyjną) oraz 
to skomplikowane zagadnienie, albowiem skopiowanie tłoczeń, ornamentów czy superekslibrisów wymaga zastosowania specjalnych narzędzi. Nie stroni się także od wykonywania opraw jubilerskich, $\mathrm{z}$ wykorzystaniem srebrnych blach i kamieni szlachetnych (choć trzeba przyznać, że najdroższe z nich, jak rubiny czy szafiry, bywają już syntetyczne) oraz szlachetnych tkanin. Rekonstruuje się również guzy i inne okucia bloku, zapinki, a także kapitałki. O ile jednak dba się o to, aby blok książki przypominał swoim stanem oryginał, o tyle nie stosuje się raczej postarzania oprawy (mogłoby to z resztą nie przynieść oczekiwanego rezultatu). Często faksymile umieszcza się w specjalnym futerale, który czasem nawiązuje do długiej historii oryginału (choćby etui stworzone na zamówienie, w którym przechowywano oryginalny egzemplarz), najczęściej jest to jednak rodzaj szkatuły, która chroni faksymile przed zniszczeniem i ułatwia jego transport i przechowywanie.

W wypadku faksymiliów sensu stricto powszechnym zwyczajem jest dołączenie opracowanego wcześniej komentarza. Objaśnia on zazwyczaj historię i proweniencję kodeksu, czasem też historię wykonywanych zabiegów konserwatorskich, a także zawiera omówienie estetycznych wartości książki. W niektórych przypadkach opisuje się cały proces powstawania faksymile, materiały, z których zostało wykonane, oraz rzadko - profil firmy wydawniczej. Ze względu na prestiżowy charakter przedsięwzięcia wydawnictwa zapraszają do współpracy wiodących przedstawicieli nauki, specjalizujących się w kodykologii czy inkunabulistyce. Redakcja takiego komentarza wymaga kwerendy wielu źródeł, analizy treści dokumentu, jego szaty graficznej, proweniencji, historii i wielodziedzinowej wiedzy, dlatego nie zawsze pracuje się w pojedynkę. Sam komentarz nie stanowi jednak integralnej całości wydawniczej z faksymile; wydawany jest jako odrębny tom, który umieszcza się wraz z reprodukcją w pudełku lub innym etui. Odróżnia to faksymile sensu stricto od wydawnictw źródłowych.

\section{FUNKCJE I CECHY FAKSYMILE}

Najważniejszym z punktu widzenia bibliologa pytaniem jest to, jaką funkcję pełni faksymile i jak odnosi się do całego uniwersum piśmiennictwa. Jest to istotny wątek, ponieważ ten rodzaj wydawnictw łączy w sobie cechy innych typów dokumentów, takich jak książka piękna, cymelium (lub szeroko pojmowane zbiory specjalne) czy wreszcie książka naukowa i współczesne wydawnictwa per se.

Rozważania te należy rozpocząć od pierwszej, zasadniczej relacji, jaką jest substytucja. Faksymile zastępuje w niektórych przypadkach dokument oryginalny, w związku z czym przejmuje część jego funkcji. Może być to zależność celowa lub przypadkowa. Najwierniejsze kopie — manuskryptów, starodruków, map

sakwową; zob. Liber Precum, Ziereis Faksimiles, https://www.ziereis-faksimiles.de/liber-precum [dostęp: 23.07.2019]. 
i innych cymeliów — zastępują dokumenty oryginalne podczas stałej ekspozycji lub długotrwałego narażenia na szkodliwe czynniki otoczenia lub działalność użytkownika. Jako iż w większości oryginały mają po kilka wieków, które zdążyły odcisnąć na nich swoje piętno, a sam nośnik (papier, pergamin, papirus) ulega czasem wręcz samoistnemu zniszczeniu, wykorzystuje się faksymile, które choć przypomina wyglądem oryginał, jest wykonane ze współczesnych, odpornych na użytkowanie materiałów. Faksymilia zastępują zatem eksponaty na wystawach stałych $\mathrm{w}$ muzeach (co oznacza stałe narażenie na działanie promieniowania z oświetlenia oraz fluktuacje temperatury i wilgotności, w wypadku oryginałów niezalecane), a także przy udostępnianiu czytelnikom w bibliotekach, archiwach i innych instytucjach. Choć same kopie mają wysoką wartość materialną, to jednak korzystanie z nich nie musi wiązać się z takimi restrykcjami jak w przypadku oryginału ${ }^{43}$. W takim wypadku faksymile chroni oryginał dzięki nienarażaniu go na wielokrotną ekspozycję. Wykorzystywanie faksymiliów jako pełnoprawnych obiektów muzealnych może jednak budzić kontrowersje. Jak pisze Leszek Jodliński,

W tym ostatnim nawet [mowa tu o Muzeum Fryderyka Chopina - P.K.] „obiekty muzealne” udają same siebie, bo (co jest okolicznością nieujawnianą na wystawie) ponad 50\% „eksponatów” to kopie, faksymile itd. Poziom zafałszowania relacji między odbiorcą a obiektem upozorowanym na autentyczny (a zatem nieposiadającym cech jego materii, historii i emocji, które uosabia) okazuje się nie do obrony ${ }^{44}$.

Kurator wystawy staje zatem przed wyborem, czy wykorzystać faksymile i poinformować o tym fakcie zwiedzającego, co może skutkować spadkiem zainteresowania, czy pogwałcić imperatyw ochrony zbiorów w celu „przydania autentyczności" ekspozycji.

Kolejnym przykładem substytucji jest wykorzystanie faksymile, gdy oryginał w jakiś sposób jest powiązany z jednym miejscem (miastem, regionem), a znajduje się $\mathrm{w}$ posiadaniu instytucji w innym (kraju, regionie etc.). Zagadnienie to nawiązuje do skomplikowanych kwestii restytucji dóbr kultury oraz migracji zbiorów wskutek różnych dziejowych zawirowań. Najbardziej oczywistym przykładem jest historia kodeksów rękopiśmiennych, które powstały w określonym rejonie geograficznym (będąc owocem jakiejś szkoły, warsztatu), stanowiły darowizny dla władców lub są ważnym świadectwem kultury danego narodu. W ciągu wie-

${ }^{43}$ Mowa tu przede wszystkim o wykonywaniu zdjęć, konieczności zakładania rękawiczek czy stosowania klinów uniemożliwiających pełne rozwarcie bloku książki, a także procedury związane z transportem i wypożyczaniem obiektów. Problemy związane z udostępnianiem manuskryptów opisała obszernie Jasmine Elizabeth Burns w części pod tytułem Difficulties of Access; zob. eadem, Digital facsimiles and the modern viewer: Medieval manuscripts and archival practice in the age of new media, ,Art Documentation: Journal of the Art Libraries Society of North America" 33, 2014, nr 2, s. 148-167.

${ }^{44}$ L. Jodliński, Czas po boomie. Muzealna Polska, „Miesięcznik Znak” 11, 2015, http:// www.miesiecznik.znak.com.pl/czas-po-boomie-muzealna-polska/ [dostęp: 24.07.2019]. 
ków wędrowały one po całym świecie, aby wreszcie, najczęściej, trafić do zbiorów którejś z większych bibliotek zagranicznych. Przywrócenie pierwotnej lokalizacji takich kodeksów (a także wszystkich innych dokumentów) z różnych względów zazwyczaj nie jest już możliwe. W takiej sytuacji pewnym rozsądnym kompromisem jest sporządzenie i ofiarowanie ,poszkodowanemu” miastu lub krajowi wiernego faksymile dokumentu. Choć nie zaspokaja to z pewnością roszczeń restytucyjnych, umożliwia podjęcie przez obdarowane takim faksymile instytucje licznych działań, takich jak badania naukowe czy ekspozycja i popularyzacja obiektu.

Tego typu działania były wielokrotnie podejmowane. W 2018 roku szwajcarskie wydawnictwo Quaternio Verlag Luzern przekazało Muzeum Miejskiemu Wrocławia faksymile XIII-wiecznego Psałterza wroctawskiego, którego oryginał znajduje się w Cambridge. Samo wydarzenie cieszyło się dużym zainteresowaniem mediów oraz lokalnego środowiska. O „zfaksymilowanie” niektórych dzieł szczególnie autografów najsłynniejszych kompozytorów niemieckich — starano się również w wypadku znajdujących się w Bibliotece Jagiellońskiej w Krakowie zbiorów tak zwanej Berlinki ${ }^{45}$.

Oprócz sporządzania kopii mikroformowych wydano również faksymile dzieł Mozarta, które spotkało się z dużym zainteresowaniem muzykologów i melomanów. Przedsięwzięcie to zostało zrealizowane jako projekt Packard Humanities Institute we współpracy z International Mozarteum Foundation ${ }^{46}$. Było to nie lada wyzwanie, ponieważ należało sporządzić kopie cyfrowe rękopisów Mozarta, które obecnie znajdują się w Berlinie, Krakowie i Paryżu ${ }^{47}$. W tym wypadku faksymile jako typ dokumentu odgrywa dodatkową rolę - łączy rozproszone w różnych miejscach fragmenty spuścizn wybitnych twórców.

Wreszcie najciekawszym chyba przykładem jest przekazanie przez USA faksymiliów katalogów dawnego księgozbioru Biblioteki Zamkowej w Łańcucie. Oryginały zostały zakupione po wojnie przez The Getty Research Institute, gdzie zostały zeskanowane i udostępnione w wersji cyfrowej ${ }^{48}$. Można by zatem powiedzieć, że sporządzenie faksymile nie było potrzebne - jednak jego wykonanie i przekazanie z jednej strony jest uzupełnieniem, „domknięciem” historii biblioteki, a także (w tym przypadku) kurtuazyjnym gestem politycznym. Faksymile umożliwia również obcowanie wszystkim zainteresowanym z dokumentem, który

45 Z. Pietrzyk, Badania „Berlinki”, „PAUza Akademicka” 2008, nr 19, s. 4, http://pauza. krakow.pl/19_4_2008.pdf [dostęp: 29.07.2019].

46 The Seven Great Operas in Facsimile Editions of Mozart's Autograph Scores, Bärenreiter, https://www.baerenreiter.com/en/catalogue/facsimiles/mozart-the-seven-great-operas/ [dostęp: 24.07.2019].

47 Mozart Facsimile Projekt, Helge Kirchberger, https://www.helge-kirchberger.at/Making-of/Interviews/Mozart-Facsimile-Projekt.html [dostęp: 24.07.2019].

48 D. Reniszewski, Faksymile dla Łańcuta, „Cenne, Bezcenne, Utracone” 2013, nr 1-4, s. 41-43, http://cennebezcenne.pl/wp-content/uploads/2017/11/CBU_2013_1-4-s-41-43_reniszewski.pdf [dostęp: 24.07.2019].

ROCZNIKI BIBLIOTECZNE

ROK LXIII, 2019

(C) for this edition by CNS 
został zakupiony do kolekcji prywatnej - i jako taki nie jest dostępny w oryginale, chyba że właśnie dla sporządzenia kopii.

Kolejną funkcją faksymiliów jest uzupełnianie bądź rekonstruowanie dokumentów oryginalnych. Przeglądając oferty antykwariatów, można natknąć się na informacje, że brakujące karty uzupełniano przez sporządzenie faksymiliów i wspólne oprawienie. Jednocześnie jednak zdarzało się, że tekst rękopisu ocalał wyłącznie dzięki zachowanemu faksymile i odwrotnie - sporządza się faksymilia na podstawie tekstów zachowanych, aczkolwiek nie jest to częste zjawisko. Przykładem mogą być choćby wydania Hortus Deliciarum — które sporządzono na podstawie zachowanych kopii w różnych wydawnictwach współczesnych (to jest po 1800 roku) oraz Liber Scivias - którego faksymile wykonano na podstawie reprodukcji sporządzonej w międzywojniu ${ }^{49}$. Ponieważ oryginalne kodeksy prawdopodobnie uległy zniszczeniu wskutek wojen, faksymilia pozostają ich najbliższymi odpowiednikami. Co więcej, nawet jeśli oryginał istnieje, to najczęściej jest unikatem ze względu na niepowtarzalne dla innych egzemplarzy cechy. Faksymilia, reprodukując wiernie właśnie ów unikat, multiplikują go wraz z właściwymi mu składowymi, dzięki czemu zniszczenie egzemplarza nie oznacza całkowitego unicestwienia dzieła.

Pozostając przy funkcjach, jakie faksymilia pełnią względem szeroko pojętego społeczeństwa (udostępnianie, ochrona, substytucja — zaspokajają bowiem cele jednostek, nie odnosząc się prawie bezpośrednio do relacji zachodzących między dokumentem oryginalnym a jego kopią per se), są one istotne dla ich posiadacza. Dla bibliofilów stają się zatem elementem kolekcji, dla bogatych lokatą kapitału, dla innych - unikatowym prezentem. Z czasem zyskują wartość sentymentalną, a przechodząc $\mathrm{z}$ rąk do rąk - własną, odmienną od oryginału proweniencję.

Nawiązując do funkcji, należy pochylić się nad immanentnymi cechami faksymiliów. Stanowiąc najczęściej odzwierciedlenie manuskryptów, starych druków czy wartościowych autografów, stają się niejako dowodem słów Przecława Smolika, który twierdzi:

Pod tym względem współczesny miłośnik i twórca „pięknej książki”, zwłaszcza w Polsce, nie zadaje sobie wcale trudu i powtarza najczęściej gotowe formy, które wytworzyły ubiegłe wieki, rezygnując w ten sposób już z góry z tej osobliwej i czarującej harmonii, wyrażonej właśnie w książce z wieków ubiegłych, w której treść przyoblekała się we właściwą, jedynie dla danej książki istniejącą i z duchem epoki zgodną formę. I jeżeli piękność inkunabułów i książek z w. XVI nazywamy dziś powszechnie niezrównaną, to mamy w tym rację o tyle, że w formie książek ówczesnych wyraził się jak najdoskonalej rytm życia ówczesnego, czyli duch epoki, gdy tymczasem my zdobywamy się tylko na naśladownictwo form, wytworzonych przez ową epokę i nie mamy

${ }^{49}$ Liber Scivias, Facsimile Finder, https://www.facsimilefinder.com/facsimiles/liber-scivias-facsimile [dostęp: 24.07.2019]; zob. też Hortus Deliciarum, Facsimile Finder, https://www.facsimilefinder.com/facsimiles/hortus-deliciarum-facsimile [dostęp: 25.07.2019].

ROCZNIKI BIBLIOTECZNE

ROK LXIII, 2019

(C) for this edition by CNS 
odwagi i siły zerwać z nimi lub raczej nie umiemy znaleźć równie doskonałego wyrazu i równie pięknej formy, która by zgodną była z duchem naszych czasów, z rytmem współczesnego życia ${ }^{50}$.

Nie bez powodu przytoczony został cytat z książki pod tytułem $O$ ksiązce pięknej, ponieważ faksymile opiera się na ,,powszechnie niezrównanym” pięknie starych dokumentów. Tutaj działalność wydawnicza nie jest wyrazem braku oryginalności, lecz świadomego nawiązania do historii i tworzenia nie na podstawie, ale ze względu na estetykę manuskryptów i innych obiektów. Smolik mianem „książki pięknej” określał książki o pięknej formie, lecz także treści, kompletny (czy może kongenialny?) owoc pracy autora, drukarza i introligatora, stosowny wobec „ducha epoki”. I mimo wtórnego charakteru faksymiliów wciąż spełniają one wymienione kryteria; co więcej, niewiele współcześnie wydawanych książek wykonywanych jest z równą starannością o jakość druku i materiałów co faksymile. Należy wziąć pod uwagę również inny aspekt produkcji najwierniejszych reprodukcji, mianowicie ręczne wykończenie stron, elementów graficznych czy oprawy. Stawia to faksymilia (w przeciwieństwie do reprintów) obok książki artystycznej, jak też wytwarza więź z oryginałem, przy którego produkcji większość prac wykonywana była manualnie. Fenomen - i zarazem słabość faksymiliów polega na tym, że jak powtarza za Walterem Benjaminem Karl Dachs ${ }^{51}$ - mimo że nie da się w pełni powielić „,aury oryginału”, należy się do takiego stanu jak najbardziej zbliżyć. Jeszcze dwadzieścia lat temu większość badaczy twierdziła zgodnie, iż nie da się w sposób nominalnie identyczny skopiować oryginału, odtworzyć właściwości podłoża, patyny lat czy detali kolorystycznych ${ }^{52}$. Jednocześnie jednak wydawcy dopełniają współcześnie wszelkich starań, aby stworzyć idealną kopię, a przy postępujących możliwościach przemysłu można przypuszczać, że ów cel zostanie kiedyś osiągnięty.

Paradoksalnie pociąga to za sobą dość nieoczekiwane następstwa. W ten sposób bowiem faksymile aspiruje do rangi cymeliów, które to, ze względu na swoją specyfikę, należą choćby do zbiorów szczególnie chronionych. Ograniczeniu ulega zatem możliwość (a zarazem funkcja) szerokiego udostępniania faksymiliów, ponieważ dostęp do nich (choćby w niektórych bibliotekach) bywa utrudniony.

\section{ZAKOŃCZENIE}

Mimo zmieniającej się roli faksymilia pozostają obecne na europejskim i światowym rynku książki. W zależności od pełnionej funkcji ewoluuje ich forma -

50 P. Smolik, O książce pięknej, Warszawa 1926, s. 14-15.

51 K. Dachs, op. cit., s. 37-38.

52 M. Kramer, Ein Faksimile ist keine Handschrift: zur Schwierigkeit des Vergleichs von Wiedergabe und Original, „Librarium: Zeitschrift der Schweizerischen Bibliophilen Gesellschaft” 29, 1986, nr 3, s. 203-207; zob. też K. Dachs, op. cit.; F. Unterkircher, op. cit. 
w dużym stopniu definiowana przez wierność odwzorowania dokumentu oryginalnego. Współcześnie faksymilia częściowo stają się produktem komercyjnym, zyskując uwagę nie tylko specjalistów, lecz także niezorientowanej w tej tematyce szerszej publiczności.

Niejednorodność uniwersum faksymiliów jest najbardziej widoczna w wypadku ich funkcji naukowej. Przybierają one różną formę; także aparat pomocniczy zmienia się w zależności od potrzeb. Konkurencją dla drukowanych wydań stały się w dodatku edycje cyfrowe, które prezentują większe możliwości eksplorowania tematu i pracy zespołowej.

Można stwierdzić, że zebranie piśmiennictwa, które powstało na temat faksymiliów pozwoliło na stworzenie solidnych podstaw do szczegółowych badań w tej dziedzinie. Na omówienie w przyszłości zasługują choćby poszczególne typy faksymiliów (na przykład faksymilia naukowe czy muzyczne), problematyka faksymiliów w wersji cyfrowej; istnieje również konieczność kontynuowania prac bibliograficznych w tym zakresie, zmierzająca (przynajmniej w przypadku najwierniejszych reprodukcji) do kompletności.

\section{BIBLIOGRAFIA}

Barkefeld P., Faksimile im Insel Verlag, München 2002.

Benjamin W., The work of art in the age of mechanical reproduction, [w:] Illuminations, red. H. Arendt, New York 1969, s. 1-26, https://web.mit.edu/allanmc/www/benjamin.pdf [dostęp: 21.07.2019].

Biblia Gutenberga i jej polskie faksymile, oprac. J. Pirożyński, T. Serocki, J. Tondel, Pelplin 2004. Burns J.E., Digital facsimiles and the modern viewer: Medieval manuscripts and archival practice in the age of new media, ,Art Documentation: Journal of the Art Libraries Society of North America" 33, 2014, nr 2, s. 148-167.

Centek B., Kozielec T., Faksymile i reprinty — sposób na zachowanie słowa drukowanego i pisanego, cz. 1, „Świat Druku” 2009, nr 10, s. 21-24.

Centek B., Kozielec T., Faksymile i reprinty - sposób na zachowanie stowa drukowanego i pisanego, cz. 2, „Świat Druku” 2009, nr 12, s. 21-24.

Dachs K., Die Konzeption von Faksimileausgaben als bibliothekarische Aufgabe, „BibliotheksForum Bayern: BFB” 14, 1986, nr 1, s. 33-49.

Facsimile edition, [w:] Oxford Companion of the Book, T. 2, red. M.F. Suarez, S.J. i H.R. Woudhuysen, Oxford 2010, s. 712.

Facsimile Finder, https://www.facsimilefinder.com/ [dostęp: 29.01.2018].

Faksimile, [w:] Lexikon der Medien- und Buchwissenschaft, T. 1, red. T. Keiderling, Stuttgart 2016, s. 249.

Faksimile-Ausgaben, [w:] Lexikon des gesamten Buchwesens, T. 2, red. S. Corsten, G. Pflug, F.A. Schmidt-Künsemüller, Stuttgart 1989, s. 538-539.

Filipek A., Model opisu dokumentu wedtug FRBR (Functional requirements for bibliographic record), „Zagadnienia Informacji Naukowej” 2005, nr 2, s. 13-30.

Głombiowski K., O funkcjonalna koncepcję nauki o książce, „Studia o Książce” 1, 1970, s. 5-24.

ROCZNIKI BIBLIOTECZNE

ROK LXIII, 2019

(C) for this edition by CNS 
Herstellung: Die Kunst der Faksimilierung, Quaternio Verlag Luzern, https:/quaternio.ch/herstellung-faksimilierung/ [dostęp: 23.07.2019].

Hilka T., Zur Terminologie und Geschichte der Faksimilierung, „Bibliothek Forschung und Praxis" 9, 1985, nr 3, s. 290-299.

Hortus Deliciarum, Facsimile Finder, https:/www.facsimilefinder.com/facsimiles/hortus-deliciarum-facsimile [dostęp: 25.07.2019].

Jodliński L., Czas po boomie. Muzealna Polska, „Miesięcznik Znak” 11, 2015, http://www.miesiecznik.znak.com.pl/czas-po-boomie-muzealna-polska/ [dostęp: 24.07.2019].

Knowlton S.A., How the current draft of RDA addresses the cataloging of reproductions, facsimiles, and microforms, „Library Resources \& Technical Services” 53, 2009, nr 3, s. 159-165.

Koeman C., An increase in facsimile reprints, „Imago Mundi” 18, 1964, s. 87-88.

Kramer M., Ein Faksimile ist keine Handschrift: zur Schwierigkeit des Vergleichs von Wiedergabe und Original, „Librarium: Zeitschrift der Schweizerischen Bibliophilen Gesellschaft”29, 1986, nr 3, s. 203-207.

Liber Precum, Ziereis Faksimiles, https://www.ziereis-faksimiles.de/liber-precum [dostęp: 23.07.2019].

Liber Scivias, Facsimile Finder, https://www.facsimilefinder.com/facsimiles/liber-scivias-facsimile [dostęp: 24.07.2019].

Mozart Facsimile Projekt, Helge Kirchberger, https:/www.helge-kirchberger.at/Making-of/Interviews/Mozart-Facsimile-Projekt.html [dostęp: 24.07.2019].

Narodowy Korpus Języka Polskiego, http://www.nkjp.uni.lodz.pl/ [dostęp: 22.07.2019].

Nieć G., O reprintach uwag kilka, „Annales Universitatis Paedagogicae Cracoviensis”2010, s. 83-98.

Pietrzyk Z., Badania „Berlinki”, „PAUza Akademicka” 2008, nr 19, s. 4, http://pauza.krakow. pl/19_4_2008.pdf [dostęp: 29.07.2019].

PN-ISO 5127:2005, Informacja i dokumentacja - Terminologia.

Reniszewski D., Faksymile dla Łańcuta, „Cenne, Bezcenne, Utracone” 2013, nr 1-4, s. 41-43, http:// cennebezcenne.pl/wp-content/uploads/2017/11/CBU_2013_1-4-s-41-43_reniszewski.pdf [dostęp: 24.07.2019].

Rylukowski E., Nowe życie starych ksiag — reprinty, „Księgarz” 20, 1976, nr 3, s. 12-24.

Smolik P., O książe pięknej, Warszawa 1926.

Sowiński J., Między oryginatem, kopia a falsyfikatem: polskie edycje faksymilowe, Kraków 2009.

Tazbir J., W królestwie reprintów, wznowień i - nieporozumień, „Wiadomości Historyczne” 1997, nr 2, s. 122-126.

The Seven Great Operas in Facsimile Editions of Mozart's Autograph Scores, Bärenreiter, https:// www.baerenreiter.com/en/catalogue/facsimiles/mozart-the-seven-great-operas/ [dostęp: 24.07.2019].

Unterkircher F., Original und Faksimile als bibliophile Sammelobjekte, [w:] Beiträge zur Buchkunde und Kulturgeschichte: Festgabe für Franz Unterkircher zum 80. Geburtstag, red. O. Mazal, Graz 1984, s. 13-19.

Zotter H., Bibliographie faksimilierter Handschriften (Internet Ausgabe), http://sosa2.uni-graz.at/ sosa/faksbib/index.php [dostęp: 23.07.2019]. 
PATRYK KOBLISCHKE

\title{
FACSIMILES AS A TYPE OF BOOK PUBLICATIONS - DEFINITION, TYPOLOGY, EDITING AND FUNCTIONS
}

\begin{abstract}
Summary
The subject of facsimiles has rarely been explored in Polish bibliology. That is why the present study is an attempt to systematise the knowledge of the subject on the basis of bibliological and scholarly sources, both Polish and foreign. Facsimiles are made to represent the most important features of documents, including the faithfulness in the reproduction of the original, content added during facsimile edition (back matter, commentary) as well as formal and editorial features. The very process of producing a facsimile consists in advanced scanning of the original document, precise printing guaranteeing faithful reproduction of colours, manual treatment (e.g. cutting of holes, gilding etc.) and binding. All these elements are to make the facsimile similar to the original as much as possible. Facsimiles serve as substitutes of original documents, making it possible to disseminate and protect the originals, and use them in research or popularising activities. Given the aesthetic and material value, they may also become collector's items or investments for potential users. Today facsimiles are undergoing transformations in the context of their roles and functions.
\end{abstract}

KEY WORDS: facsimile, book reproduction, scholarly editing 